\title{
PENGARUH MODEL PEMBELAJARAN ARIAS DAN COOPERATIVE SCRIPT TERHADAP MINAT DAN HASIL BELAJAR MATEMATIKA
}

\author{
Jaka Wijaya Kusuma ${ }^{1 \bowtie}$, Hamidah $^{2}$ \\ ${ }^{1,2}$ Universitas Bina Bangsa
}

\begin{tabular}{|c|c|}
\hline Info Artikel & Abstract \\
\hline $\begin{array}{l}\text { Sejarah Artikel: } \\
\text { Diterima 24 Mei } \\
\text { 2019 } \\
\text { Direvisi 22 Juni } 2019 \\
\text { Disetujui 23 Juni } \\
2019\end{array}$ & $\begin{array}{l}\text { The purpose of this study is three, namely 1) to determine the effect of the ARIAS learning model on } \\
\text { student mathematics learning outcomes; 2) to find out the effect of Cooperative Script learning models } \\
\text { on student mathematics learning outcomes; and 3) to determine the effect of ARIAS and Cooperative } \\
\text { Script learning models on student learning interest groups. The sample in this study was grade VIII } \\
\text { students at the Tirtayasa-Serang Middle School. The research method used was the quasi- } \\
\text { experimental method with the design of the pretest-posttest control group design. The results of the } \\
\text { study revealed that 1) There was a significant effect of the ARIAS learning model on students' } \\
\text { mathematics learning outcomes; 2) There is a significant effect of Cooperative Script learning models }\end{array}$ \\
\hline Keywor & $\begin{array}{l}\text { on students' mathematics learning outcomes; and 3) ARIAS and Cooperative Script learning models } \\
\text { have a positive influence on student learning interest. }\end{array}$ \\
\hline
\end{tabular}

Cooperative Script,

Learning Outcomes

\section{Paper type:}

Research paper

\begin{abstract}
Abstrak
Tujuan dari penelitian ini ada tiga yaitu 1) untuk mengetahui pengaruh model pembelajaran ARIAS terhadap hasil belajar matematika siswa; 2) untuk mengetahui pengaruh model pembelajaran Cooperative Script terhadap hasil belajar matematika siswa; dan 3) untuk mengetahui pengaruh model pembelajaran ARIAS dan Cooperative Script terhadap kelompok minat belajar siswa. Sampel dalam penelitian ini adalah siswa kelas VIII di SMP Kecamatan Tirtayasa-Serang. Metode penelitian yang digunakan adalah metode kuasi eksperimen dengan desain pretest-postest control group design. Hasil penelitian diketahui bahwa 1) Terdapat pengaruh yang signifikan model pembelajaran ARIAS terhadap hasil belajar matematika siswa; 2) Terdapat pengaruh yang signifikan model pembelajaran Cooperative Script terhadap hasil belajar matematika siswa; dan 3) Model pembelajaran ARIAS dan Cooperative Script memberi pengaruh positif terhadap minat belajar siswa.
\end{abstract}

(C) 2019 Universitas Muria Kudus

\footnotetext{
Alamat korespondensi:

Program Studi Pendidikan Matematika

Fakultas Keguruan dan Ilmu Pendidikan Universitas Muria Kudus

Kampus UMK Gondangmanis, Bae Kudus Gd. L. It I PO. BOX 53 Kudus

Tlp (0291) 438229 ex.147 Fax. (0291) 437198

E-mail: jakawijayak@binabangsa.ac.id
}

p-ISSN 2615-4196

e-ISSN 2615-4072 


\section{PENDAHULUAN}

Heyneman \& Lee, (2016) menyebutkan bahwa tingkat pendidikan seseorang memberi pengaruh terhadap kemungkinan seseorang tersebut menjadi pengangguran dan terjebak dalam kemiskinan. Sehingga perlulah mengejar pendidikan setinggi-tingginya. Namun demikian diketahui masih rendahnya pendidikan matematika yaitu dari hasil perolehan nilai ujian akhir Nasional untuk jenjang SMP dan SMA/ SMK yang skornya relatif rendah. Rendahnya hasil belajar matematika siswa dapat disebabkan oleh banyak hal diantaranya kurikulum yang padat, materi pada buku pelajaran yang dirasakan terlalu banyak, sulit untuk di ikuti, dan media belajar yang kurang efektif. Lebih lanjut, penyebabnya juga dapat dikarenakan kurang tepatnya penggunaan metode pembelajaran yang dipilih oleh guru dan kurangnya keselarasan siswa itu sendiri dimana siswa tidak banyak terlibat dalam proses pembelajaran.

Dari berbagai faktor penyebab rendahnya hasil belajar matematika tersebut, penulis lebih fokus terhadap kekurangnya ketepatan para guru dalam memilih model pembelajaran. Faktor model pembelajaran merupakan faktor utama yang mampu mempengaruhi hasil belajar siswa khususnya matematika. Model Pembelajaran menurut Kardi dan Nur (Hariyanto, 2011) ada lima model pembelajaran yang dapat digunakan dalam mengelola pembelajaran, yaitu: pembelajaran langsung; pembelajaran kooperatif; pembelajaran berdasarkan masalah; diskusi; dan learning strategi

Paradigma pembelajaran lama yaitu guru memberikan pengetahuan kepada siswa secara pasif tanpa memberikan kesan terhadap memori siswa. Lebih lanjut, guru cendrung tidak melibatkan siswa dalam proses pembelajaran. Namun demikian, masih banyak guru yang mengajar dengan metode ini atau lebih dikenal dengan metode ceramah yaitu mengharapkan siswa duduk, mendengarkan, mencatat, dan mengerjakan latihan.

Selain itu kita ketahui bahwa pada setiap diri siswa mempunyai minat belajar yang berbeda, ada siswa yang minat belajarnya tinggi dan ada pula yang rendah. Oleh karena itu setiap guru harus dapat memahami dan mengamati minat belajar siswa selama prose pembelajaran berlangsung agar masing-masing siswa dapat secara optimal selama di kelas. Guru tidak hanya berfungsi sebagai pengajar melainkan juga harus berfungsi sebagai pendidik, pembimbing, pelatih dan pengarah bagi siswa-siswanya. Guru diharapkan mampu menggapai siswanya untuk yakin pada diri sendiri sehingga mampu menyemangati siswa untuk berupaya keras dan pantang menyerah dalam menghadapi segala tantangan dan rintangan dalam belajar yang akhirnya akan menghasilkan prestasi belajar yang optimal.

Mulyana, et.al. (2008), menyebutkan bahwa untuk membangun minat belajar sedikitnya ada tiga elemen yang diperlukan yaitu fokus pada persoalan yang jelas, gagasan atau informasi baru, dan forum atau basis untuk berkomunikasi. Sutjipto (Olivia. O, 2009) menjelaskan bahwa minat adalah kesadaran seseorang terhadap suatu objek, orang, masalah, atau situasi yang mempunyai kaitan dengan dirinya. Hal ini menunjukan bahwa minat harus dipandang sebagai sesuatu yang sadar. Karenanya minat merupakan aspek psikologis seseorang untuk menaruh perhatian yang tinggi terhadap kegiatan tertentu dan mendorong yang bersangkutan untuk melaksanakan kegiatan tersebut.

Seperti yang diungkapkan oleh Mulyana, et.al. (2008) bahwa seseorang yang berminat untuk belajar akan tertarik pada bidang studi atau pokok bahasan tertentu dan merasa senang untuk mempelajari materi tersebut. Ini berarti, minat menjadi sumber pendorong yang kuat dalam hubungannya dengan dengan orang lain, benda, kegiatan, dan sebagainya dalam rangka pemenuhan keinginan terhadap sesuatu yang disenanginya.

Lucy (2009) menyebutkan bahwa minat belajar merupakan langkah yang pertama. Menurutnya, minat itu muncul dari dalam diri sendiri atau daripada keadaan di sekeliling. Faktor paling utama yang mempengaruhi minat belajar adalah cita-cita. Jadi cara yang paling baik adalah fikirkan dulu cita- cita yang hendak dicapai agar minat belajar semakin tinggi. Lucy (2009) juga menyebutkan bahwa percaya kepada diri sendiri merupakan langkah penentu dan modal yang harus dimiliki seseorang guna memotivasi dirinya.

Hal di atas menunjukkan perlunya suatu rancangan model pembelajaran yang dapat menarik minat siswa serta mengaktifkan siswa saat proses pembelajaran. Model pembelajaran yang dimaksud yaitu model pembelajaran ARIAS. Model pembelajaran ARIAS dikembangkan oleh Keller dan Kopp tahun 1987 yaitu model pembelajaran ARIAS terdiri dari lima komponen yaitu assurance (percaya diri), relevance (relevansi), interest (minat/perhatian), assessment (evaluasi), dan satisfaction (kepuasan/rasa bangga) (Hamidah, 2008). Selanjutnya, dalam penelitian Ardi (2013) diperoleh hasil nilai rata-rata kelas dengan menggunakan model pembelajaran ARIAS 
lebih tinggi yaitu sebesar 80,11 daripada nilai ratarata kelas kontrol yaitu 74,45 sehingga dapat disimpulkan bahwa penerapan model pembelajaran ARIAS dengan pendekatan CTL berpengaruh positif terhadap hasil belajar siswa.

Lebih lanjut, Menurut Lie (2010) model pembelajaran kooperatif merupakan model pembelajaran yang dapat meningkatkan semangat kerja sama dan saling berkomunikasi secara aktif saat pembelajaran berlangsung serta memberikan kesempatan kepada siswa untuk berani dan mampu membagikan ide-ide dan mempertimbangkan jawaban yang paling tepat. Salah satu model pembelajaran kooperatif adalah model script yaitu pembelajaran yang mengatur interaksi siswa seperti ilustrasi kehidupan sosial siswa dengan lingkungannya sebagai individu, dalam keluarga, kelompok masyarakat, dan masyarakat yang lebih luas. Hal ini didukung oleh pendapat Susiloyoga, (2016) yaitu model pembelajaran cooperative script cocok digunakan untuk meningkatkan ide-ide baru khususnya dalam memecahkan suatu permasalahan serta kenumbuhkan keberanian dalam menyampaikan hal-hal baru yang diyakininya benar.

Model pembelajaran cooperative script merupakan pembelajaran yang mengajak siswa bekerja dengan pasangan dan memahami bagian bagian dari konsep pelajaran yang sedang dipelajari. Slavin (2006) mengatakan bahwa model pembelajaran yang mampu meningkatkan kemampuan siswa dalam mengingat adalah pembelajaran dengan model cooperative script.

Seiring dengan fenomena tersebut, penulis tertarik untuk melakukan penelitian dengan judul "Pengaruh model pembelajaran ARIAS dan cooperative script terhadap minat dan hasil belajar matematika".

Secara umum penelitian ini bertujuan untuk (1) Mengetahui pengaruh model pembelajaran ARIAS terhadap hasil belajar matematika siswa

Mengetahui pengaruh model pembelajaran Cooperative Script terhadap hasil belajar matematika siswa; dan (2) Mengetahui pengaruh model pembelajaran ARIAS dan Cooperative Script terhadap kelompok minat belajar siswa

\section{METODE PENELITIAN \\ Desain Penelitian}

Studi ini dirancang dalam bentuk kuasi eksperimen dengan desain pretest-postest control group design. Populasi dalam penelitian ini adalah seluruh siswa kelas VIII SMPN di Tirtayasa, Serang-Banten, sedangkan sampelnya adalah siswa kelas VIII SMPN yang ditetapkan secara cluster sampling pada SMPN di Tirtayasa tersebut.

\section{Teknik Pengolahan Data Penelitian}

Teknik pengumpulan data minat belajar siswa dilakukan dengan cara memberikan angket minat belajar matematik kepada kedua kelas yang diteliti. Selanjutnya, Teknik pengumpulan data hasil belajar matematika siswa dilakukan dengan cara memberi soal tes matematika kepada kedua kelas sebelum pembelajaran (pretest) dan setelah pembelajaran. (postest).

Dalam penelitian ini pengolahan data diawali dengan pengelompokan siswa berdasarkan minat belajar siswa tinggi dan rendah dari masingmasing kelompok kelas.

Tabel 1. Pengolahan Data Hasil Penelitian

\begin{tabular}{lccc}
$\begin{array}{l}\text { Strategi } \\
\text { belajar } \\
\text { Minat } \\
\text { belajar }\end{array}$ & K-1 & K-2 & $\sum B$ \\
\hline B-1 & $\mathrm{Y}_{11}$ & $\mathrm{Y}_{12}$ & $\sum B_{1}$ \\
B-2 & $\mathrm{Y}_{21}$ & $\mathrm{Y}_{22}$ & $\sum B_{2}$ \\
$\sum K$ & $\sum K_{1}$ & $\sum K_{2}$ & $\sum t$ \\
\hline
\end{tabular}

Keterangan:

$$
\begin{aligned}
\mathrm{K}-1= & \text { Hasil belajar matematika dengan } \\
& \text { Model Pembelajaran ARIAS } \\
\mathrm{K}-2= & \text { Hasil belajar matematika dengan } \\
& \text { Pembelajaran Cooperative Script } \\
\mathrm{B}-1= & \text { Minat belajar siswa tinggi } \\
\mathrm{B}-2= & \text { Minat belajar siswa rendah } \\
\mathrm{Y}_{11}= & \text { Hasil belajar Matematika siswa } \\
& \text { dengan pembelajaran ARIAS dan } \\
& \text { minat belajar siswa tinggi } \\
= & \text { Hasil belajar Matematika siswa } \\
& \text { dengan pembelajaran Cooperative } \\
& \text { Script dan minat belajar siswa } \\
& \text { tinggi } \\
\mathrm{Y}_{12} & \text { Hasil belajar Matematika siswa } \\
& \text { dengan pembelajaran ARIAS dan } \\
& \text { minat belajar siswa rendah } \\
= & \text { Hasil belajar Matematika siswa } \\
& \text { dengan pembelajaran Cooperative } \\
& \text { Script dan minat belajar siswa } \\
& \text { rendah. }
\end{aligned}
$$

Data hasil tes kedua kelompok diolah dengan langkah sebagai berikut:

1. Menghitung rata-rata dan simpangan baku.

2. Menguji normalitas data sampel.

3. Uji Perbedaan Rata-Rata.

4. Uji Anova.

5. Uji Chi Square dan Koefisien Kontingensi.

Adapun Tabel 2 merupakan tabel statistik deskriptif yang berisi harga-harga untuk setiap 
unsur yang diperlukan dalam ANOVA sebagai berikut:

Tabel 2. Tabel Statistik Deskriptif untuk ANOVA

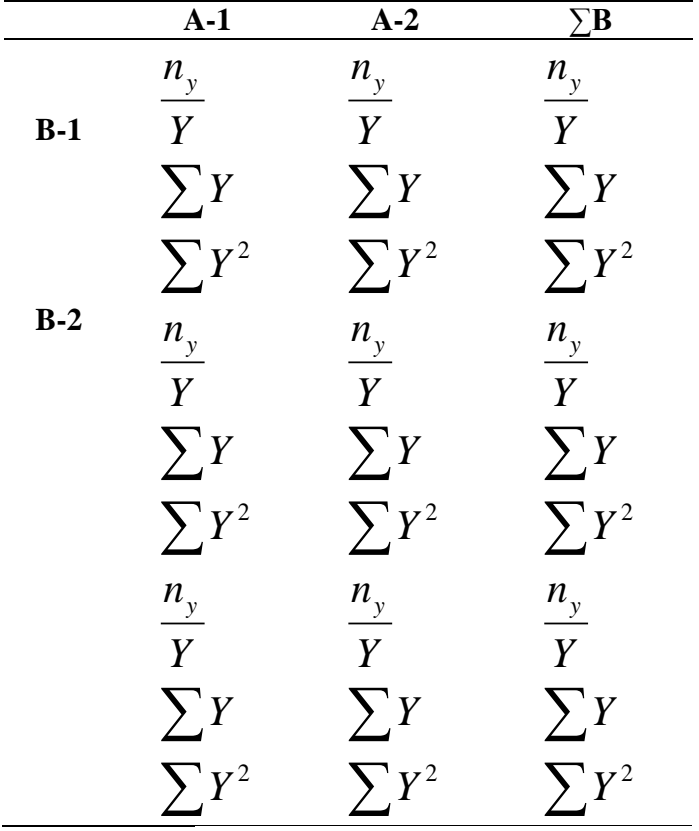

Keterangan:

$$
\begin{aligned}
& \mathrm{n}_{\mathrm{y}} \quad=\text { banyaknya subyek dalam kelompok } \\
& \mathrm{Y} \quad=\text { rerata sor untuk masing-masing } \\
& \text { kelompok } \\
& \sum \mathrm{Y} \quad=\text { jumlah skor dalam setiap kelompok } \\
& \sum \mathrm{Y}^{2} \quad=\text { jumlah kuadrat setiap skor dalam } \\
& \text { kelompok }
\end{aligned}
$$

\section{HASIL DAN PEMBAHASAN}

Data-data ukuran pusat dan letak serta simpangan/keragaman di atas, dirangkum seperti pada Tabel 3 berikut.

Tabel 3. Rangkuman Data Deskriptif

\begin{tabular}{ccccccccc}
\hline Kel N & \multirow{8}{*}{$\begin{array}{c}\text { Skor Hasil Belajar } \\
\text { Mean }\end{array}$} & Modus $\begin{array}{c}\text { Medi Varia } \\
\text { Max }\end{array}$ & Min & SD \\
\hline A & 26 & 24 & 10 & 19,3 & 20 & 19,5 & 10,1 & 2,8 \\
C & 26 & 22 & 10 & 16,4 & 16,4 & 16,3 & 7,9 & 3,2 \\
AT & 13 & 23 & 10 & 18,2 & 19,6 & 18,8 & 12,5 & 3,5 \\
AR & 13 & 24 & 16 & 20,3 & 15,8 & 21,7 & 6,2 & 2,5 \\
CT & 13 & 21 & 10 & 16,5 & 22,4 & 16,6 & 7,3 & 2,7 \\
CR & 13 & 22 & 12 & 16,4 & 15,5 & 19,4 & 9,3 & 3,1 \\
\hline
\end{tabular}

Keterangan:
$\mathrm{A}=$ Hasil belajar matematika siswa yang diajar dengan model pembelajaran ARIAS.
$\mathrm{C}=$ Hasil belajar matematika siswa yang diajar dengan model pembelajaran cooperative script
AT = Hasil belajar matematika siswa dengan tingkat Minat belajar tinggi, diajarkan dengan model pembelajaran ARIAS.

\section{$\mathrm{AR}=$ Hasil belajar matematika siswa dengan tingkat Minat belajar rendah, diajarkan dengan model pembelajaran ARIAS \\ $\mathrm{CT}=$ Hasil belajar matematika siswa dengan tingkat Minat belajar tinggi, diajarkan dengan model pembelajaran cooperative script. \\ $\mathrm{CR}=$ Hasil belajar matematika siswa dengan tingkat Minat belajar rendah, diajarkan dengan model pembelajaran cooperative script.}

Tabel 3 di atas menunjukkan, bahwa nilai rerata (mean) yang paling besar adalah nilai ratarata kelompok AR (kelompok siswa diajar dengan model pembelajaran ARIAS dengan tingkat Minat belajar rendah). Ini menunjukkan, apabila siswa diajar melalui model pembelajaran ARIAS dan siswa memiliki tingkat Minat belajar rendah, secara umum akan menghasilkan hasil belajar matematika lebih tinggi daripada siswa yang memiliki minat belajar tinggi atau dengan kata lain model pembelajaran ARIAS secara umum efektif diberikan kepada siswa yang berminat belajar rendah. Sedangkan rerata terendah diperoleh kelompok CR (kelompok siswa dengan tingkat Minat belajar rendah, diajar dengan model pembelajaran cooperative script), ini menunjukkan bahwa siswa yang memiliki tingkat Minat belajar rendah dan diajar dengan model pembelajaran cooperative script akan menghasilkan hasil belajar matematika yang rendah atau dengan kata lain secara umum

\begin{tabular}{|c|c|c|c|c|c|}
\hline $\begin{array}{l}\text { Sumber } \\
\text { Varians }\end{array}$ & Db & JK & RJK & Fh & $\begin{array}{c}\text { Ft } \\
\alpha= \\
0,05\end{array}$ \\
\hline Kolom (Ak) & 1 & 105,31 & 105,31 & 11,94 & 4,02 \\
\hline Baris (Ab) & 1 & 43,00 & 43 & 4,88 & 4,02 \\
\hline Interaksi (I) & 1 & 285,08 & 285,08 & 32,32 & 4,02 \\
\hline $\begin{array}{l}\text { Kelompok } \\
\text { (A) }\end{array}$ & 3 & 433,38 & 144,46 & 16,38 & - \\
\hline $\begin{array}{l}\text { Kelompok } \\
\text { (D) }\end{array}$ & 48 & 423,38 & 8,8204 & - & - \\
\hline $\begin{array}{l}\text { TReduksi } \\
\text { (TR) }\end{array}$ & 51 & 856,76 & 16,799 & - & - \\
\hline Rerata ( R) & 1 & 16561,23 & 16561 & - & - \\
\hline Total (T) & 52 & 17417,96 & - & - & - \\
\hline
\end{tabular}
pembelajaran matematika tidak efektif dengan model cooperative script untuk siswa yang berminat belajar rendah.

Tabel 4. Rangkuman Hasil Perhitungan Teknik ANOVA Dua Jalur. 
Dari tabel 4 di atas diketahui bahwa hasil analisis data pada kelompok model pembelajaran matematika antara model pembelajaran ARIAS dan model pembelajaran cooperative script (antar kolom) diperoleh harga $F_{\text {hitung }}=11,94$ lebih besar dari harga $F_{\text {tabel }}=4,02$ pada tingkat signifikansi $\alpha$ $=5 \%$. Ini berarti dalam pengujian hipotesis pertama menolak $\mathrm{H}_{0}$ dan menerima $\mathrm{H}_{1}$, dengan demikian dapat disimpulkan bahwa secara signifikan terdapat pengaruh model pembelajaran terhadap hasil belajar matematika.

Dari label 24 (tabel rangkuman hasil perhitungan teknik ANOVA dua jalur) di atas, diperoleh bahwa terdapat interaksi antara model pembelajaran dengan minat belajar siswa terhadap hasil belajar matematik yaitu yang menganalisis varians pada empat kelompok data hasil belajar matematika (kelompok ARIAS minat tinggi, ARIAS minat rendah, cooperative script minat tinggi dan cooperative script minat rendah) diperoleh harga $\mathrm{F}_{\text {hitung }}=32,32$ lebih besar dari harga $F_{\text {tabel }}$ sebesar 4,02 pada tingkat $\alpha=5 \%$. Hasil ini menunjukkan penolakan $\mathrm{H}_{0}$ dan menerima $\mathrm{H}_{1}$, dengan demikian hipotesis ketiga teruji kebenarannya dan dapat diterima. Dengan demikian dapat disimpulkan terdapat pengaruh model pembelajaran dan minat belajar terhadap hasil belajar matematika siswa.

Berdasarkan hasil pengamatan selama memberikan pembelajaran dengan dua model tersebut diketahui bahwa pembelajaran dengan model ARIAS lebih mengajak siswa untuk lebih aktif. Lebih lanjut siswa menunjukkan sikap yang positif terhadap pembelajaran dengan model ARIAS atau dengan kata lain pembelajaran dengan model ARIAS adalah pembelajaran yang menyenangkan.

Dalam prakteknya, pembelajaran dengan model ARIAS membiasakan mengadakan kegiatan pembelajaran yang ada relevansinya dengan kehidupan siswa, berusaha menarik dan memelihara minat/perhatian siswa. Kemudian diadakan evaluasi dan menumbuhkan rasa puas dan bangga pada siswa dengan memberikan penguatan atau penghargaan. Hal ini merupakan salah satu factor yang mempengaruhi perhatian siswa untuk terus mengikuti pembelajaran sampai selesai yang kemudian memberikan dampak positif terhadap hasil belajar matematik siswa.

Lebih lanjut, adanya komponen assurance yaitu berhubungan dengan sikap percaya, yakin akan berhasil atau yang berhubungan dengan harapan untuk berhasil. Seperti yang disampaikan oleh Petri (1986) bahwa sikap percaya, yakin atau harapan akan berhasil mendorong individu bertingkah laku untuk mencapai suatu keberhasilan. Hal ini juga didukung oleh Prayitno (1989) bahwa siswa yang memiliki sikap percaya diri memiliki penilaian positif tentang dirinya cenderung menampilkan prestasi yang baik secara terus menerus.

Pada kelas eksperimen II (pembelajaran dengan model cooperative script) siswa cenderung bosan dengan adanya strategi pengelompokkan siswa. Hal ini dikarenakan ada beberapa siswa yang tidak senang dengan kelompok yang diberikan sehingga kurang menyenangi proses pembelajaran yang akhirnya berdampak terhadap hasil belajar siswa. Lebih lanjut, ada beberapa siswa yang merasa terbebani dengan adanya peran sebagai pembicara atau sebagai pendengar yang harus menyimak dan mengoreksi. Mereka cenderung merasa takut salah atau takut tidak lebih baik dari kelompok lain, sehingga konsentrasi untuk memahami materi menjadi berkurang. Hal lain yaitu adanya kekurangan dari model pembelajaran cooperative script yaitu hanya digunakan untuk mata pelajaran tertentu dan hanya dilakukan dua orang (tidak melibatkan seluruh kelas sehingga koreksi hanya sebatas pada dua orang tersebut). Hal ini tentunya memberikan dampak negative terhadap hasil belajar matematik siswa.

Jika ditinjau dari interaksi antara model pembelajaran dan klasifikasi minat belajar siswa terhadap hasil belajar matematiknya diketahui bahwa terdapat interaksi antara model pembelajaran dengan minat belajar siswa terhadap hasil belajar matematik atau secara uji statistik terdapat pengaruh model pembelajaran dan minat belajar terhadap hasil belajar matematika siswa.

Hal ini menunjukkan bahwa keempat pasangan kelompok yaitu kelompok pertama; kelompok dengan pembelajaran model ARIAS dan kelompok klasifikasi minat belajar matematik tinggi, kelompok kedua; kelompok dengan pembelajaran model ARIAS dan kelompok klasifikasi minat belajar matematik rendah, kelompok ketiga; kelompok dengan pembelajaran model cooperative script dan kelompok klasifikasi minat belajar matematik tinggi, dan kelompok keempat kelompok dengan pembelajaran model cooperative script dan kelompok klasifikasi minat belajar matematik rendah, masing masing memiliki perbedaan yang signifikan tiap kelompok pasangannya.

Dengan kata lain, model pembelajaran dan minat belajar siswa berinteraksi dalam mempengaruhi kemampuan matematik siswa (hasil belajar matematik siswa). 


\section{SIMPULAN}

Studi ini memberikan kesimpulan yaitu model pembelajaran ARIAS dan coperative script memberi pengaruh positif yang signifikan terhadap hasil belajar dan minat belajar matematika siswa.

Selama penelitian ditemukan bahwa diperlukan kerjasama antar guru matematika dalam mengoptimalkan kemampuan siswanya dalam belajar matematika. Kerjasama ini sebagai sarana tukar pengalaman mengajar sesuai model pembelajaran dan metode yang digunakan oleh masing-masing guru. Lebih lanjut guru perlu mengetahui tingkat minat belajar siswanya dalam belajar matematika sedini mungkin, sebagai langkah awal membina dan meningkatkan hasil belajar mereka.

Berdasarkan hasil penelitian diketahui bahwa hasil belajar matematika kelompok siswa yang diajar dengan model ARIAS berminat belajar tinggi lebih rendah dari rata-rata hasil belajar matematika kelompok siswa yang diajar dengan model ARIAS berminat belajar rendah. Berdasarkan hal tersebut dapat disimpulkan bahwa pembelajaran dengan model ARIAS lebih cocok diberikan kepada siswa yang minat belajarnya masih rendah. Pembelajaran model ARIAS yang dalam proses pembelajarannya menekankan pada menarik minat siswa tentunya memberi pengaruh yang lebih besar terhadap siswa yang minat belajarnya masih rendah, sehingga dapat memberi dampak positif terhadap hasil belajar matematika siswa.

Sedangkan pada kelompok siswa yang diajar dengan model cooperative script berminat belajar tinggi diperoleh rata-rata (mean) yang lebih tinggi dari kelompok yang diajar dengan model cooperative script berminat belajar rendah. Berdasarkan hal ini dapat disimpulkan bahwa model cooperative script lebih cocok diberikan kepada siswa yang minat belajarnya sudah tinggi. Hal ini dikarenakan model cooperative script lebih menuntut keterampilan siswa dalam berbicara atau menyampaikan hasil penyimakan dan kurang memperhatikan minat siswa terlebih dahulu untuk mengikuti pembelajaran. Sehingga siswa yang minat belajarnya masih rendah kurang merespon proses pembelajaran.

\section{DAFTAR PUSTAKA}

Ardi, R.S, dkk. 2013. Pengaruh Model Pembelajaran ARIAS dengan Pendekatan CTL Terhadap Hasil Belajar Biologi Siswa Kelas VII SMPN 1 Padang. Jurnal Pendidikan, 63(1): 63-69
Arikunto, S. 2006. Dasar-dasar Evaluasi Pendidikan Edisi Revisi. Jakarta: Bumi Aksara

-------------. 2006. Prosedur Penelitian Suatu Pendekatan Praktek. Jakarta: Rineka Cipta

Djamarah, S.B. dan Zain, A. 2006. Strategi Belajar Mengajar. Jakarta: Rineka Cipta

Depdiknas. 2005. Materi Pelatihan Terintegrasi Matematika Buku 3. Jakarta: Depdiknas

Hakim, L. 2008. Perencanaan Pembelajaran. Bandung: Wacana Prima.

Heyneman, S. P., \& Lee, B. 2016. International Organizations and The Future of Education Assistance. International Journal of Educational Development, 9-22.

Sanjaya, W. 2007. Strategi Pembelajaran Berorientasi Standar Proses Pendidikan. Jakarta: Kencana Prenada Media Group

Slavin, R.E., 2006. Accommodating student diversity in reading and writing instruction: a cooperative learning approach, Journal of Technology Education, 18 (1): 52-55

Sumiati, dan Asra. 2008. Metode Pembelajaran. Bandung: Wacana Prima

Susiloyoga, J. 2016. Upaya Meningkatkan Kemampuan Menentukan Peluang Suatu Kejadian dengan Model Pembelajaran Kooperative Script pada Siswa Kelas IXIPA 3 SMA Negeri 2 Madiun. Jurnal Ilmiah Edukasi Matematika, 39-62.

Syah, M. 2008. Psikologi Pendidikan dengan Pendekatan Baru. Bandung: Remaja Rosdakarya. 